\title{
Magnetostratigraphy of the Cretaceous/Tertiary boundary and early Paleocene sedimentary sequence from the Chicxulub Impact Crater
}

\author{
Mario Rebolledo-Vieyra* and Jaime Urrutia-Fucugauchi \\ Laboratorio de Paleomagnetismo, Instituto de Geofisica, UNAM, Circuito Exterior S/N, Cd. Universitaria, Coyoacan, D.F., 04510, Mexico
}

(Received December 20, 2005; Revised June 4, 2006; Accepted June 7, 2006; Online published November 8, 2006)

\begin{abstract}
We report on the magnetostratigraphy of the Chicxulub crater impact breccias and first 15 meters of the Paleocene sedimentary sequence recovered in three boreholes of the UNAM Scientific Drilling Program. Three geomagnetic polarity zones are documented in the impact breccias and sedimentary sequence, which span from chron $29 \mathrm{R}$ to $28 \mathrm{~N}$. For the $15 \mathrm{~m}$ interval they represent $\sim 2.5 \mathrm{Ma}$, which yields low apparent sedimentary rates for boreholes UNAM-5 (110 km from the center of the crater) and UNAM-7 (127 km from the center of the crater). The carbonate sedimentary sequence can be associated to a shallow basin depositional environment. In these boreholes the thickness between the $29 \mathrm{R}$ and the $29 \mathrm{~N}$ chrons is just $0.5 \mathrm{~m}$, suggesting that during the 100 $\mathrm{ka}$ from the $\mathrm{K} / \mathrm{T}$ boundary to the polarity transition sediments were not deposited or eroded. Within borehole UNAM-6 (152 km from the center of the crater) it appears that sediments containing chron $29 \mathrm{~N}$ are missing, the lack of the upper breccias, the long duration of a reversal event within the base of the sequence and low apparent sedimentary rate of $3.3 \mathrm{~m} / \mathrm{Ma}$, suggests a hiatus within the impact breccias and the basal Paleocene sedimentary sequence. Magnetic susceptibility logs confirm absence of the upper breccias at UNAM-6 borehole. Magnetic susceptibility values increase towards the base of the sequence, suggesting that basement and melt clasts were subjected to a low temperature hydrothermal alteration.
\end{abstract}

Key words: Chicxulub Crater, Cretaceous/Tertiary boundary, magnetostratigraphy, paleomagnetism, Gulf of Mexico.

\section{Introduction}

Several studies have been conducted in the last fifteen years on the Chicxulub impact crater, which have greatly contributed to our understanding of the crater structure, characteristics and its formation, and on the effects of the impact event. The Chicxulub impact has been related to the events marking the Cretaceous/Tertiary $(\mathrm{K} / \mathrm{T})$ boundary and to the extinction of organisms. However several questions remain unanswered, particularly those related to the post-impact processes. One of the questions is the reestablishment of sedimentary deposition within the crater and the nature of the contact between the impact breccias and the Tertiary carbonates. Controversies exist regarding many aspects of the $\mathrm{K} / \mathrm{T}$ boundary stratigraphy and the impact ejecta layer, its age and its relationship to the $\mathrm{K} / \mathrm{T}$ extinction are also controversial in several aspects (e.g., Ward et al., 1995; Smit, 1999; Keller et al., 2004; UrrutiaFucugauchi et al., 2004a). Therefore it is important to study the sedimentary record and reconstruct the paleoenvironment of the impact basin. In this paper, we report results of the magnetostratigraphy obtained from three boreholes of

*Present address: Centro de Investigación Científica de Yucatán, CICY, Mérida, Yucatán, México.

Copyright (C) The Society of Geomagnetism and Earth, Planetary and Space Sciences (SGEPSS); The Seismological Society of Japan; The Volcanological Society of Japan; The Geodetic Society of Japan; The Japanese Society for Planetary Sciences; TERRAPUB. the UNAM Scientific Drilling Program, UNAM-5, UNAM6 and UNAM-7 (Fig. 1), corresponding to the upper (melt and basement-rich clasts) breccias, the breccias-carbonates contact and the first $15 \mathrm{~m}$ of the Tertiary carbonate sequence.

\section{Stratigraphy}

As part of the UNAM scientific drilling program 8 boreholes have been drilled in the southern sector of the crater (Fig. 1), with high core recovery rates (up to $99 \%$ in UNAM-5, with overall average recovery rates of $\sim 87 \%$ ) that permit detailed stratigraphic investigation. Three boreholes sampled the impact lithologies (UNAM-5, UNAM6 and UNAM-7), which are here used for the paleomagnetic and rock magnetic investigations. Two units are documented as impact lithologies, an upper breccia sequence (comparable to the suevitic and bunte breccias documented in the Ries crater, Von Engelhardt, 1990; Newsom et al., 1990). In UNAM-5 (Fig. 2(a)), the contact with the Tertiary carbonates is at $332.0 \mathrm{~m}$ deep and the upper breccias have a thickness of $146 \mathrm{~m}$ (the borehole did not reach the bottom of the unit). In UNAM-7, it is $126.1 \mathrm{~m}$ thick (Fig. 2(b)) and the contact with the Tertiary carbonates is at $222.2 \mathrm{~m}$ deep. The lower breccias (carbonate-rich or bunte type, also described in the Ries crater, Stöffler, 1977; Hörz et al., 1983; Von Engelhardt, 1990; Newsom et al., 1990) in UNAM-7 lies at $348.4 \mathrm{~m}$ deep, with a thickness of $180 \mathrm{~m}$ (Fig. 2(b)). In UNAM-6, the upper breccias are not present; 

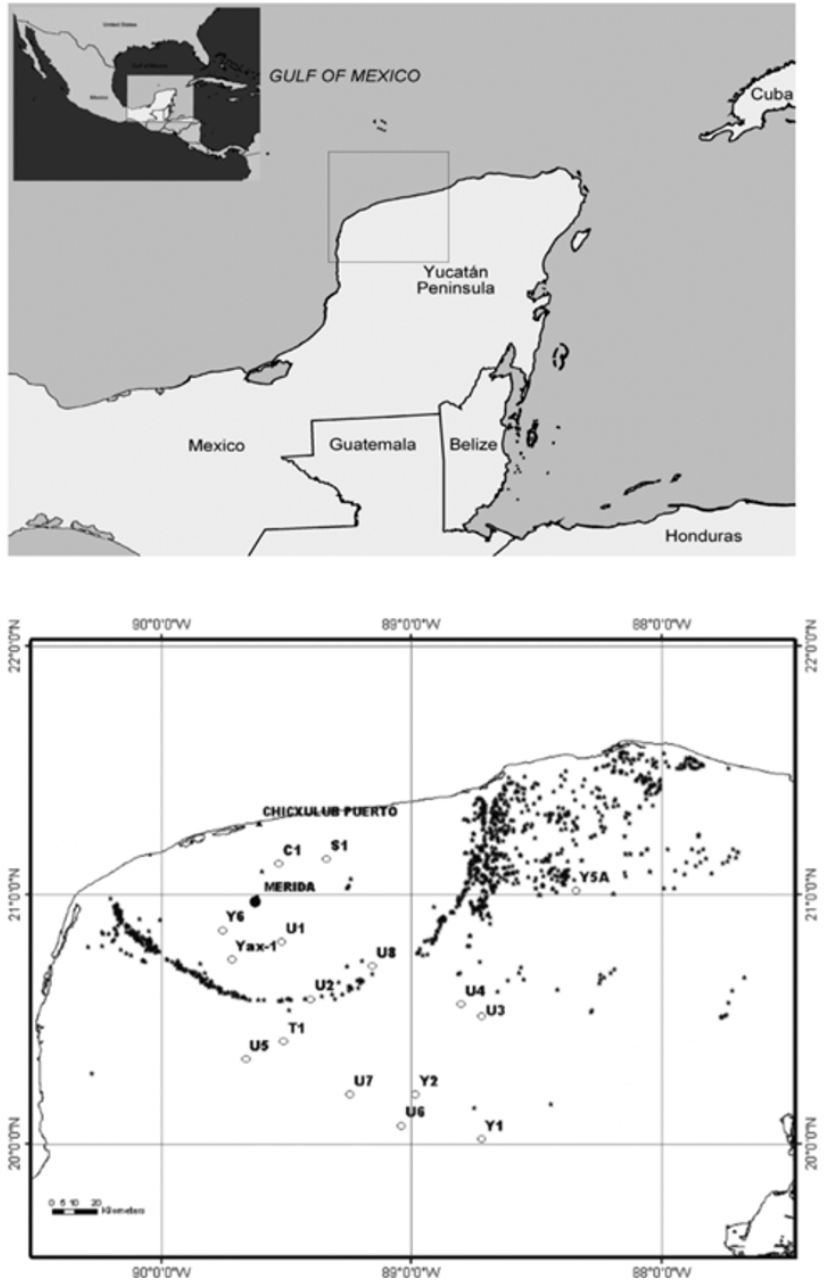

Fig. 1. Upper box Map of Mexico showing the Yucatan Peninsula. Lower box map showing location of the boreholes: PEMEX: Chicxulub-1, C1; Sacapuc-1, S1; Ticul-1, T1; Yucatan-1, Y1; Yucatan-2, Y2; Yucatan-5a, Y5a; Yucatan-6, Y6; UNAM boreholes: UNAM-1, U1; UNAM-3, U3; UNAM-4, U4; UNAM-5, U5; UNAM-6, U6; UNAM-7, U7; UNAM-8, U8 and Yaxcopoil-1, Yax-1. Stars indicate sinkholes, locally called "cenotes". (Modified from Urrutia-Fucugauchi et al., 2004a).

the contact of the lower breccias and Tertiary carbonates is at $282.8 \mathrm{~m}$ deep; the thickness is $153.7 \mathrm{~m}$ (Fig. 2(c)). The presence of angular to sub-rounded clasts from the crystalline basement (gneiss, diorite), fragments of melt and impact glass (black and dark green) and shocked quartz grains permits correlation with the upper breccias in UNAM-5 (Fig. 2(a)) and UNAM-7 (Fig. 2(b)). The distribution of the clasts within the breccias is highly heterogeneous; this is a matrix-supported unit with the same bulk composition as the clasts (crystalline basement, melt, impact glass and occasionally carbonate clasts). Size of clasts ranges from gravel to blocks (up to $5 \mathrm{~cm}$ in diameter). It is important to point that the unit below the Tertiary carbonates of UNAM5 corresponds to re-deposited sandstone. This sandstone is gray colored, fine grained and well sorted; it shows planar and cross-bedded stratification. The magnetic susceptibility $\log$ (Rebolledo-Vieyra and Urrutia-Fucugauchi, 1999) indicates that the magnetic mineralogy is similar to that of the upper breccias. The cross-bedding and sorting suggest that this unit is re-deposited. The lower unit of UNAM-5 is a

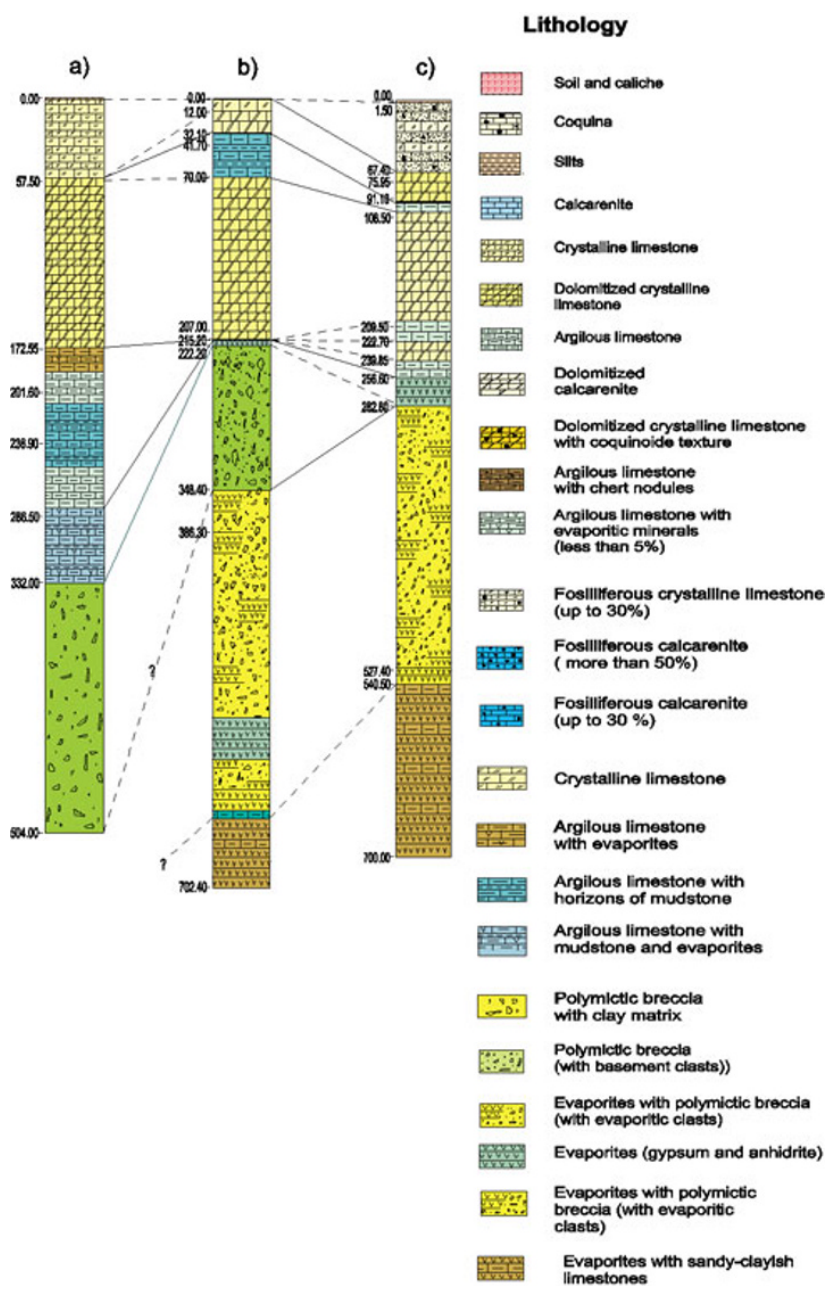

Fig. 2. Lithologic correlation of the three boreholes. A) UNAM-5, Santa Elena, b) UNAM-7, Tekax; b) UNAM-6, Peto; (Modified from Rebolledo-Vieyra et al., 2000).

matrix-supported breccia. The distribution of clasts is also highly heterogeneous, and the size of the clasts ranges from gravel to block size (up to $25 \mathrm{~cm}$ ), the composition is mainly carbonate, crystalline limestones and anhydrite. The color is light brown to gray. Some clasts are strongly altered and the original lithology is difficult to identify. The next unit that can be correlated is a unit of dolomitized crystalline limestones, which forms the bulk of the carbonate sequence and is characterized by light cream to dark brown colors, compact appearance and a high degree of fracturing and fragmentation. Dolomitization appears in bands, replacing bivalves and corals by magnesium carbonate.

\section{Time Constrains}

Determining the age of the Chicxulub impact with adequate resolution to establish correlation with e.g., the K/T ejecta clay layer, marine and continental paleontological records and other volcanic and tectonic events has remained a difficult problem. Hildebrand et al. (1991) proposed after reviewing available geophysical, stratigraphic and borehole information for the Chicxulub impact structure (e.g., Lopez Ramos, 1973; Penfield and Camargo, 1981) that the impact had a K/T age. However, the stratigraphy for the Cretaceous 


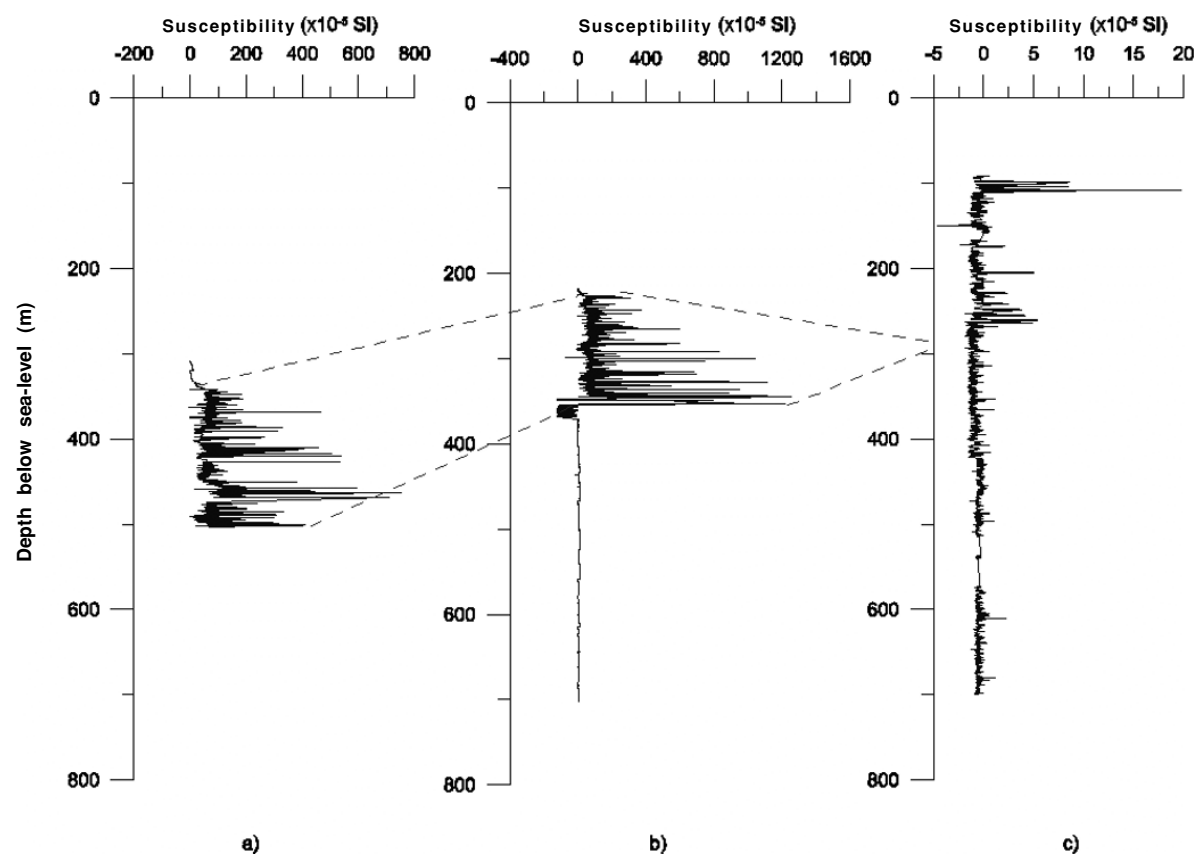

Fig. 3. Susceptibility behavior in a) UNAM-5 borehole, b) UNAM-7 borehole and c) UNAM-6 borehole. Boreholes are in radial order from the center of the crater. Units are in SI $\times 10^{-5}$. Dashed lines indicate the section corresponding to the melt-rich upper breccias.

and Tertiary carbonate sediments and the impact lithologies has been a matter of some debate (e.g., Ward et al., 1995); recently, also in regarding the correlation of the impact with K/T extinction event (e.g., Keller et al., 2004).

Constraints on the impact age derived directly from impact melt rocks and breccias from inside the Chicxulub crater have been reported from geochronological and magnetic polarity stratigraphy. Sharpton et al. (1992) and Swisher et al. (1996) reported ${ }^{40} \mathrm{Ar} /{ }^{39} \mathrm{Ar}$ ages for samples of melt rock from the Chicxulub-1 borehole of approximately 65 Ma. Urrutia-Fucugauchi et al. (1994) reported the reverse polarity magnetization for a sample of melt from borehole Yucatan-6, which is correlated to the 29R chron which spans the $\mathrm{K} / \mathrm{T}$ boundary according to the reference geomagnetic polarity time scale (Cande and Kent, 1995).

More recently, Marin et al. (2001) based on analyses of carbonate sediment samples from PEMEX's borehole Y-6 concluded that the marine sediments underlying the impact rocks are Upper Cretaceous and that the $\mathrm{K} / \mathrm{T}$ boundary is located in this borehole between 1000 and $1103 \mathrm{~m}$ (depth from ground level). This is in agreement with a K/T boundary age for the Chicxulub impact.

However, stringent constraints on impact age are required for correlation of the impact event with global ejecta layer and paleontological data in marine and continental records. Temporal resolution allowed in most studies do not permit accurate constraints within a couple of thousands years, which is the age difference proposed in Keller et al. (2004) for the K/T extinction and Chicxulub impact.

\section{Methods}

We sampled the cores from the three boreholes that recovered the impact breccia sequences (UNAM-5, UNAM-6 and UNAM-7) (Figs. 1 and 2). Details of the drilling and coring methods employed in the drilling program, includ- ing core diameters and lithological description, are given in Rebolledo-Vieyra et al. (2000). Cubic samples were cut from the cores every $50 \mathrm{~cm}$, depending on the preservation conditions of the cores, starting at the last meter of the upper (melt and basement-rich) breccias and ending approximately $15 \mathrm{~m}$ above the contact between the upper breccias and the carbonate sequence, averaging 30 samples for each borehole.

Samples were analyzed in a Super Quantum Interference Device (SQUID) cryogenic magnetometer with background noise of $10^{-9} \mathrm{~A} / \mathrm{m}$, at the Paleomagnetic Laboratory of the California Institute of Technology, in Pasadena, CA. The samples were subjected to AF demagnetization from 0-100 $\mathrm{mT}$ in $10 \mathrm{mT}$ steps, afterwards were thermally demagnetized from $0-400^{\circ} \mathrm{C}$ in $100^{\circ} \mathrm{C}$ steps, then $450^{\circ} \mathrm{C}, 500^{\circ} \mathrm{C}$, $525^{\circ} \mathrm{C}$ and $550^{\circ} \mathrm{C}$. Samples from the upper breccias had a magnetic intensity within the range of $10^{-4} \mathrm{~A} / \mathrm{m}$ and about $10^{-7} \mathrm{~A} / \mathrm{m}$ for carbonates and evaporites. Most of the samples were demagnetized between $300^{\circ} \mathrm{C}$ and $400^{\circ} \mathrm{C}$ (Fig. 3); these intermediate unblocking temperature spectra characteristics forced us to use the $\mathrm{AF}$ and the $100^{\circ} \mathrm{C}$ and $200^{\circ} \mathrm{C}$ steps to calculate the mean characteristic direction of the samples. Since our samples came from borehole cores, without azimuthal orientation, declination was not considered and we use for the final analysis to determine the magnetic polarity only the characteristic inclination. For the calculations we assumed a relative declination and used standard least-squares fit (Kirschvink, 1980) and statistics (Fisher, 1953) to determine the mean characteristic inclination and polarity (Fig. 4).

\section{Magnetic Susceptibility Core Logging}

Urrutia-Fucugauchi et al. (1996, 2004b) reported results on the behavior of the magnetic susceptibility in boreholes UNAM-6 and UNAM-7 and Yaxcopoil-1; we extended the 
A
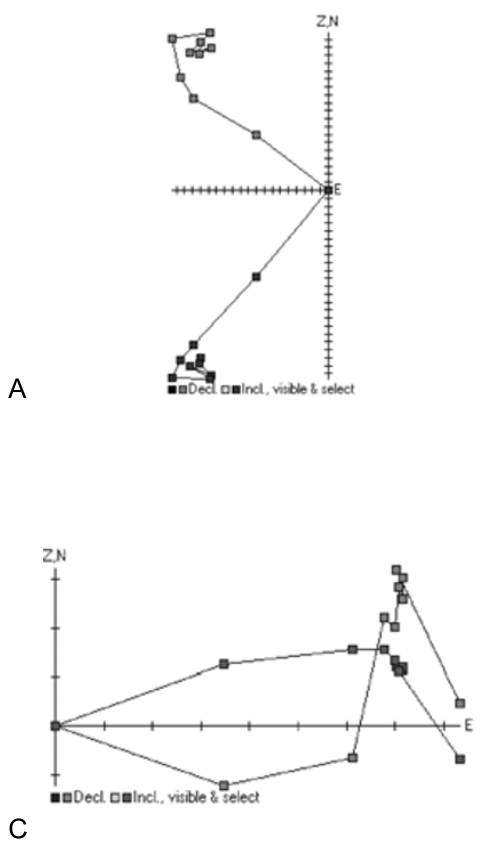

$\mathrm{E}$

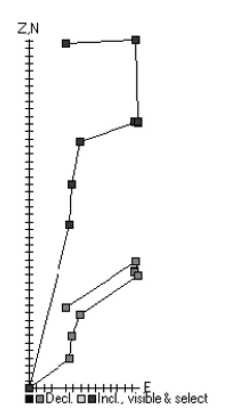

B

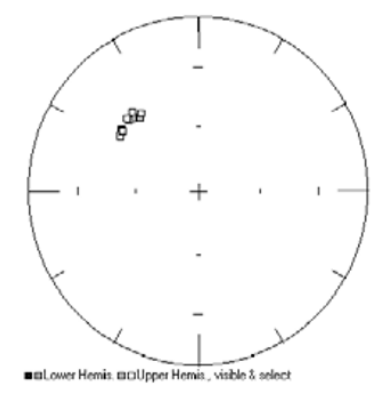

D

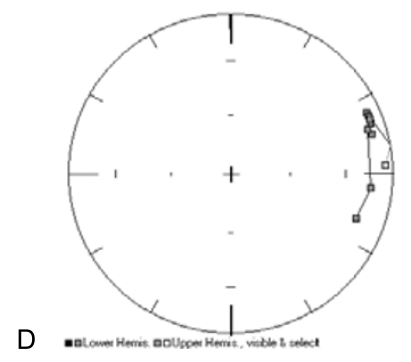

$\mathrm{F}$

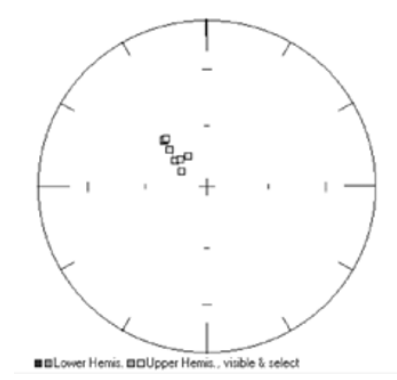

Fig. 4. Examples of Zijderveld demagnetization vector diagrams for: a) Sample of upper breccias from UNAM-7; b) Sample of lower breccias from UNAM-6; c) Sample of crystalline-limestone from UNAM-5. Least-squares fits have a maximum angular deviation of $<10^{\circ}$.

study on these boreholes and in addition included UNAM5. Our aim has been to obtain high-resolution magnetic susceptibility $\operatorname{logs}$ to characterize the impact lithologies. Lowfield magnetic susceptibility was measured with the Bartington MS2 system and a core-logging sensor. Measurements were taken at $10-\mathrm{cm}$ spacing. UNAM-5 was measured between $308.00 \mathrm{~m}$ to $468.65 \mathrm{~m}$ (Fig. 3(a)), UNAM6 was measured between $91.60 \mathrm{~m}$ to $700.00 \mathrm{~m}$ (Fig. 3(c)) and UNAM-7 was measured between $218.35 \mathrm{~m}$ to $702.00 \mathrm{~m}$ (Fig. 3(b)), in UNAM-6 we started at $91.6 \mathrm{~m}$. The magnetic susceptibility contrast, between the impact lithologies and the carbonates, is high enough in UNAM-7 to establish accurately the contact between them. Susceptibility displays a simple pattern, values from, carbonates, dolomitized carbonates, marls, anhydrite and evaporitic breccias, are within the diamagnetic and paramagnetic range (Fig. 3). The upper breccias display high values, UNAM-5 highest value is $463.8 \times 10^{-5}$ SI (Fig. 3(a)), and UNAM-7 (Fig. 3(b)) displays higher values, up to $1252.5 \times 10^{-5}$ SI. A remarkable feature, in both boreholes, is the increment of the susceptibility towards the base of the unit. In UNAM-7, magnetic susceptibility drops from $1252.5 \times 10^{-5}$ SI to the diamagnetic range, this drop marks the contact between the upper (melt-rich breccias) and lower breccias (carbonatesrich breccias) (Fig. 3(b)), that indicates the contact be- tween the upper and lower breccias, in UNAM-7, at 346.95 m. In the measurements of UNAM-6 (Fig. 3(c)), we observed a homogeneous behavior of the susceptibility along the core, with values within the diamagnetic and paramagnetic ranges. This shows a lack of ferrimagnetic minerals in this borehole, indicating that the absence of the melt-rich breccias. Only the lower breccias are present, with composition similar to that of the carbonate target lithologies (Rebolledo-Vieyra et al., 2000). UNAM-5 exhibits a similar behavior than that of UNAM-7 for the upper breccias; but we could not estimate the contact with the lower breccias, because this borehole did not reached this unit.

\section{Magnetostratigraphy}

Four polarity chrons were detected for the three boreholes, two reverse (29R and 28R) and two normal (29N and 28N) (Figs. 5, 6 and 7). The tie point assumed at $65 \mathrm{Ma}$ was taken from the radiometric ages of the upper breccias from Y6 borehole from PEMEX (Swisher et al., 1996), which correlates the breccias to the chron $29 \mathrm{R}$ (Urrutia-Fucugauchi et al., 1994). In boreholes UNAM-5 and UNAM-7, the polarity of the samples of upper breccias is reverse, followed by carbonate sediments with normal polarity. We interpreted this polarity change as the transition from chron 29R to chron 29N (Fig. 5 and 7). In bore- 

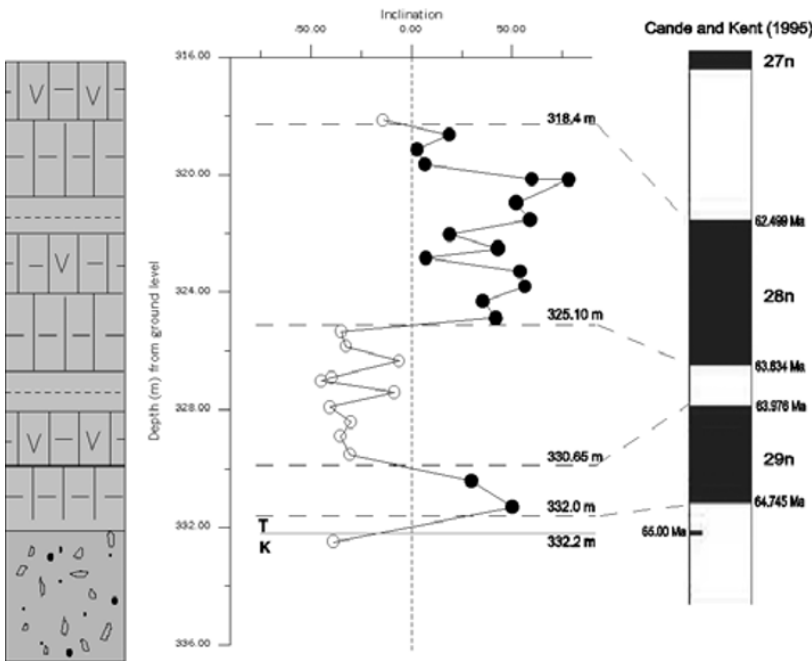

Fig. 5. Lithology, magnetostratigraphy and age constrains for borehole UNAM-5. $\mathrm{K}=$ Cretaceous; $\mathrm{T}=$ Tertiary; continuous line $=\mathrm{K} / \mathrm{T}$ boundary. Lithology legend as in Fig. 2.

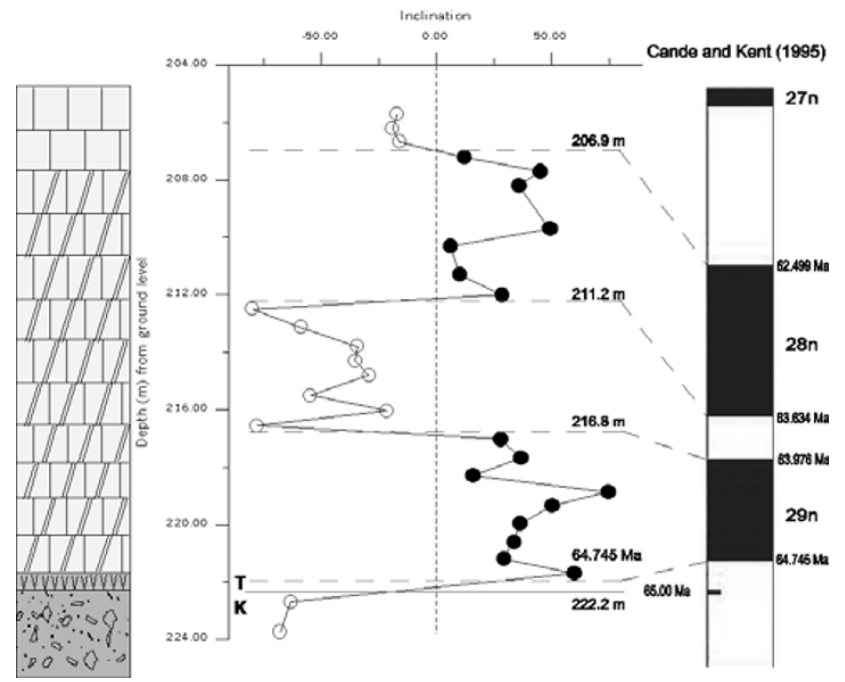

Fig. 6. Lithology, magnetostratigraphy and age constrains for borehole UNAM-7. $\mathrm{K}=$ Cretaceous; $\mathrm{T}=$ Tertiary; continuous line $=\mathrm{K} / \mathrm{T}$ boundary. Lithology legend as in Fig. 2.

hole UNAM-6, we observed a long reverse polarity zone (Fig. 6), which spans from the upper breccias to the first 3-4 meters of the Tertiary carbonates, in this case, we interpreted this long reverse zone, as absence of the sedimentary sequence containing chron $29 \mathrm{~N}$, probably due to erosion or non-deposition of the sedimentary sequence coeval with this chron. In UNAM-6, the magnetic susceptibilities are within the diamagnetic range along the sequence of the borehole $(502 \mathrm{~m})$, which supports our interpretation that the melt-rich upper breccias are missing as interpreted from the magnetostratigraphy.

Once the magnetostratigraphy was established, we estimate the apparent sedimentary rate (ASR) for each borehole using the equation of Johnson and McGee (1983):

$$
\begin{aligned}
\Delta t & =S \tau N \\
S & =\frac{-\ln (1-2 P)}{2}
\end{aligned}
$$
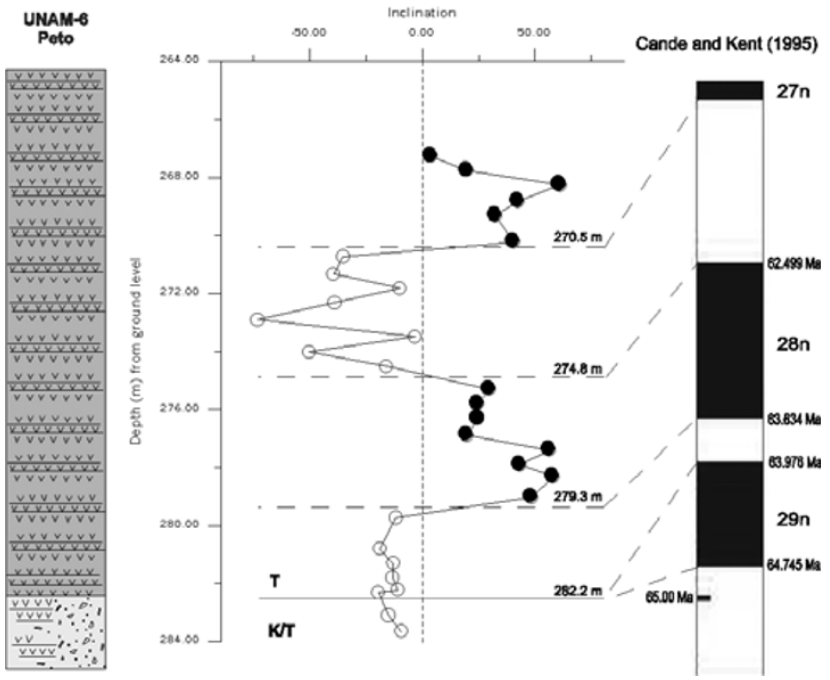

Fig. 7. Lithology, magnetostratigraphy and age constrains for borehole UNAM-6. $\mathrm{K}=$ Cretaceous; $\mathrm{T}=$ Tertiary; continuous line $=\mathrm{K} / \mathrm{T}$ boundary. Lithology legend as in Fig. 2.

Table 1. Parameters and apparent sedimentary rates calculated for each borehole.

\begin{tabular}{cccccccc}
\hline Borehole & $D(\mathrm{~m})$ & $\tau(\mathrm{Ma})$ & $N$ & $S$ & $R$ & $\delta \mathrm{t}(\mathrm{Ma})$ & $s r(\mathrm{~m} / \mathrm{Ma})$ \\
\hline UNAM-5 & 15 & 0.748 & 26 & 0.137 & 3 & 2.66 & 5.68 \\
UNAM-6 & 15 & 1.241 & 22 & 0.168 & 3 & 4.58 & 3.32 \\
UNAM-7 & 15 & 0.748 & 24 & 0.150 & 3 & 2.69 & 5.65 \\
\hline
\end{tabular}

$$
\begin{aligned}
P & =\frac{R}{N-1} \\
s r & =\frac{d}{\Delta t}
\end{aligned}
$$

$\tau=$ arithmetic mean of the duration of the polarities within the sequence

$S=$ Sediments accumulated

$N=$ Number of intervals sampled

$R=$ Number of reversals within the sequence

$D=$ Thickness of the sequence

$s r=$ Sedimentary rate

The sedimentary rates calculated for each borehole are summarized in Table 1. Boreholes UNAM-5 and UNAM-7 show similar ASR values, since they have the same number of polarity changes and the same number of chrons, within the approximate same thickness. These sedimentary rates are low, and may be explained in two ways. A low sedimentary depositional rate in a small shallow basin; according to Sadler (1981) accumulation rates for time spans of $\sim 108$ years, can be as low as $1 \mathrm{~m} / \mathrm{Ma}$. An alternative interpretation is in terms of erosional events that remove part of the sequence.

\section{Conclusions}

The magnetic susceptibility core logs exhibit an increasing trend towards the base of the upper breccias probably as a consequence of hydrothermal alteration of the magnetic minerals. Studies of the magnetic mineralogy of the impact breccias from borehole Yaxcopoil-1, indicated that magnetic carriers are mainly low-temperature magnetites 
formed as alteration products at temperatures under $150^{\circ} \mathrm{C}$ (Urrutia-Fucugauchi et al., 2004b; Pilkington et al., 2004).

We tied the magnetostratigraphy with the radiometric age of the impact melt at $65 \mathrm{Ma}$ within chron 29R. Estimates of apparent sedimentation rates for the carbonate sequence give low values, suggesting that part of the impact breccias and the base of the Tertiary carbonate sequence have been eroded. In UNAM-6 borehole the upper breccias are not present, indicating a major hiatus. Considering a diameter of the crater between 180 and $200 \mathrm{~km}$ (Hildebrand et al., 1991; Pope et al., 1996; Urrutia-Fucugauchi et al., 2004a) and the location of the boreholes from the center of the crater (UNAM-5, $110 \mathrm{~km}$; UNAM-6, $152 \mathrm{~km}$ and UNAM-7, 127), we interpret the low apparent sedimentation rates as a consequence of a hiatus between the top of the impact breccias and the base of the Tertiary carbonates. Studies based on microfossils, stable isotopes and magnetostratigraphy from borehole Yaxcopoil-1 drilled within the crater reported a hiatus between the top of the impact breccias and the base of the Tertiary carbonate sequence (Keller et al., 2004; Rebolledo-Vieyra and UrrutiaFucugauchi, 2004). The results support that the Chicxulub crater and the surrounding region were likely subjected to post-impact erosive and re-deposition events, probably due to back-wash processes inside the basin. However, it is not clear if the three boreholes were subjected to similar erosional processes and if the magnitude of the hiatus is the same; therefore, further studies within the crater and the $\mathrm{K} / \mathrm{T}$ sections to the south of the crater are important.

Acknowledgments. This contribution is part of the UNAM Chicxulub Scientific Drilling Program. Partial financial support for this project has been provided by Conacyt G 32526-T grant and DGAPA-UNAM IN-115006 grant. We thank Prof. Joe Kirschvink from CALTECH for allowing us to use his laboratory for the paleomagnetic analyses, we also thank the comments and suggestions provided by the two journal reviewers and the invitation and editorial assistance of the Special Volume editors.

\section{References}

Cande, S. C. and D. V. Kent, Revised calibration of the geomagnetic polarity timescale for the Late Cretaceous and Cenozoic, Journal of Geophysical Research, 100(B4), 6093-6095, 1995.

Fisher, R. A., Dispersion on a sphere, Proc. Roy. Soc. London, A217, 295$305,1953$.

Hildebrand, A. R., G. T. Penfield, D. A. Kring, M. Pilkington, A. Camargo, S. B. Jacobsen, and W. V. Boyton, Chicxulub Crater: A possible Cretaceous/Tertiary boundary impact crater on the Yucatan Peninsula, Mexico, Geology, 19, 867-871, 1991.

Hörz, F., R. Ostertag et al., Bunte breccia of the Ries: Continous Deposits of large Impact Crater, Reviews of Geophysical Space Physics, 21, 1667-1725, 1983.

Johnson, N. M. and V. E. McGee, Magnetic polarity stratigraphy: Stochastic properties of data, sampling problems, and the evolution of interpretations, Journal Geophysical Research, 88, 1213-1221, 1983.

Keller, G., W. Stinnesbeck, T. Adatte, M. Rebolledo-Vieyra, J. UrrutiaFucugauchi, U. Kramar, and Stüben, D., Chicxulub impact predates K$\mathrm{T}$ boundary mass extinction, Proceedings of the National Academy of Sciences, 101, 11, 3753-3758, 2004.

Kirschvink, J. L., The least-square line and plane and the analysis of palaeomagnetic data, Geophysical Journal of the Royal Astronomical Society, 62, 699-718, 1980.
Lopez-Ramos, E., Estudio geologico de la Peninsula de Yucatan, Asociacion Mexicana de Geologos Petroleros, Boletin, 25, 23-76, 1973.

Marin, L. E., V. L. Sharpton, J. Smit, P. Sikora, C. Carney, and M. Rebolledo-Vieyra, Stratigraphy at ground zero: A contemporary evaluation of well data in the Chicxulub impact crater, International Geology Review, 43, 12, 1145-1149, 2001.

Newsom, H. G., G. Graup, D. Fseri, J. Geissman, and K. Keil, The formation of the Ries crater, West Germany: Evidence of atmospheric interactions during a large cratering event, in Global Catastrophes in Earth History: An Interdisciplinary conference on Impacts, Volcanism and Mass Mortality, edited by V. L. Sharpton and P. D. Ward, Geol. Soc. Am. Sp. Pap., 247, pp. 196-206, 1990.

Penfield, G. T. and A. Camargo, Definition of a major igneous zone in the central Yucatan platform with aeromagnetics and gravity, Soc. Explor. Geophys. Annu. Meeting, Tech. Progr. Abstracts, 51, 37 (abstr), 1981.

Pilkington, M., D. E. Ames, and A. R. Hildebrand, Magnetic mineralogy of the Yaxcopoil-1 core, Chicxulub crater, Meteoritics and Planetary Sciences, 39, 831-842, 2004.

Pope, K. O., A. C. Ocampo, G. L. Kinsland, and R. Smith, Surface expression of the Chicxulub crater, Geology, 24, 527-530, 1996.

Rebolledo-Vieyra, M. and J. Urrutia-Fucugauchi, High-resolution magnetic susceptibility record of the impact lithologies of the Chicxulub impact crater, EOS, Transactions American Geophysical Union, 80, 46. F595, 1999.

Rebolledo-Vieyra, M. and J. Urrutia-Fucugauchi, Magnetostratigraphy of the impact breccias and post-impact carbonates from borehole Yaxcopoil-1, Chicxulub impact crater, Yucatan, Mexico, Meteoritics and Planetary Science, 39(6 and 7), 821-830, 2004.

Rebolledo-Vieyra, M., J. Urrutia-Fucugauchi, L. Marin, A. Trejo-Garcia, A. M. Soler-Arechalde, and V. L. Sharpton, UNAM Scientific Shallow Drilling Program of the Chicxulub impact crater, International Geology Review, 42, 948-972, 2000.

Sadler, P. M., Sediment accumulation rates and the completeness of stratigraphic sections, Journal of Geology, 89, 569-584, 1981.

Sharpton, V. L., G. B. Dalrymple, L. E. Marin, G. Ryder, B. C. Shuraytz, and J. Urrutia-Fucugauchi, New links between the Chicxulub impact structure and the Cretaceous/Tertiary boundary, Nature, 359, 819-821, 1992.

Smit, J., The global stratigraphy of the Cretaceous-Tertiary boundary impact ejecta, Annu. Rev. Earth Planet. Sci., 25, 75-113, 1999.

Smit, J., S. V. D. Gaast et al., Is the transition impact to post-impact rock complete? Some remarks based on XRF scanning, electron-microprobe, and thin section analyses of the Yaxcopoil-1 core in the Chicxulub crater, Meteoritics and Planetary Sciences, 39(6-7), 1113-1126, 2004.

Stöffler, D., Research drilling Nördlingen 1973: polymictic breccias, crater basement and cratering model of the Ries impact crater, Geol. Bavarica, 75, 443-458, 1977.

Swisher, C. C. and 11 others, Coeval ${ }^{40} \mathrm{Ar} /{ }^{39} \mathrm{Ar}$ ages of 65.0 million years ago from Chicxulub crater melt rock and Cretaceous/Tertiary boundary tektites, Science, 257, 954-958, 1996.

Urrutia-Fucugauchi, J., L. Marin, and V. L. Sharpton, Reverse polarity magnetized melt rocks from the Cretaceous/Tertiary Chicxulub structure, Yucatan peninsula, Mexico, Tectonophysics, 237, 105-112, 1994.

Urrutia-Fucugauchi, J., J. Morgan, D. Stoeffler, and P. Claeys, (Eds), The Chicxulub Scientific Drilling Project, Meteoritics and Planetary Sciences, 39(6 and 7), 2004a.

Urrutia-Fucugauchi, J., A. M. Soler-Arechalde, M. Rebolledo-Vieyra, and P. Vera-Sánchez, Paleomagnetic and rock-magnetic study of the Yaxcopoil-1 impact breccia sequence, Chicxulub impact crater (Mexico), Meteoritics and Planetary Sciences, 39(6 and 7), 843-856, 2004b.

Von Engelhardt, W., Distribution, petrography and shock metamorphism of the ejecta of the Ries crater in Germany-A review, Tectonophysics, 171, 259-273, 1990.

Ward, W. C., G. Keller, W. Stinnesbeck, and T. Adatte, Yucatan subsurface stratigraphy: Implications and constraints for the Chicxulub impact, Geology, 23, 873-876, 1995.

M. Rebolledo-Vieyra and J. Urrutia-Fucugauchi (e-mail: juf@ geofisica.unam.mx) 